Undas Vol 12. , Nomor 1, Juni 2016 : 75--86

\title{
"HUJAN" DALAM PUISI KARYA SONI FARID MAULANA
}

\author{
"Raining" in Poetry by Soni Farid Maulana
}

\author{
Siti Akbari \\ Balai Bahasa Kalimantan Selatan \\ Jalan Jenderal Ahmad Yani Km 32,2, Loktabat, Banjarbaru 70712 Kalimantan Selatan \\ Telepon (0511) 4772641, Pos-el: akbarihdj@yahoo.co.id
}

\begin{abstract}
Abstrak: Analisis ini dilakukan berdasarkan kesadaran adanya sesuatu yang berharga pada karya yang diapresiasi. Bertolak dari keinginan menghargai karya puisi yang dihasilkan oleh Soni Farid Maulana, penulis menganalisis puisi karyanya dengan menitikberatkan perhatian pada kehadiran kata 'hujan'. Data diperoleh melalui kajian pustaka, dianalisis dengan pendekatan struktural semiotik, dengan penyajian deskriptif kualitatif. Hasil analisis menunjukkan bahwa kehadiran kata 'hujan' sebagai latar dapat mendukung suasana yang kesepian, ketidakpastian, kesyahduan, penuh birahi, dan kesedihan yang mendalam dalam puisi-puisi karya Soni Farid Maulana.
\end{abstract}

Kata kunci: apresiasi puisi, latar hujan, struktural semiotik

Abstract: The analysis was conducted based on the awareness of the existence of something of value on the work that is appreciated. Based on the desire to appreciate poetry produced by Soni Farid Maulana, the authors analyze poems by focusing attention on the presence of the word 'rain'. Data obtained through literature review, analyzed by structural semiotic approach, with the presentation of qualitative descriptive. The analysis showed that the presence of the word 'rain' in the background to support the atmosphere of loneliness, uncertainty, in a state of calm, full of lust and anguish in the poetry of Soni Farid Maulana.

Key words: Poetry appreciation, against the rain, structural semiotic.

\section{PENDAHULUAN}

Memahami puisi secara mendalam dapat dilakukan dengan apresiasi puisi. Melalui apresiasi puisi seseorang dapat merasakan apa yang ditulis penyair, mampu menyerap nilai-nilai yang terkandung di dalam puisi, dan menghargai puisi sebagai karya seni dengan keindahan maupun kelemahannya (Waluyo, 2002: 44).

Sajak tampil sebagai suara seseorang yang menjadi bagian dari kehidupan dalam dinamika peristiwa keseharian yang kadang sederhana saja. Sajak-sajak itu ibarat pergulatan memberi makna pada segala peristiwa. Eksistensi rohani memahami dirinya dalam aneka benturan antara kenyataan dan impian, kesakitan dan kebahagiaan, nafsu badani dan kedalaman rohani, cinta erotik dan cinta Ilahi.

$$
\text { Sajak sebagai perwujudan }
$$
kreativitas, pada dasarnya merupakan konsentrasi dan intensifikasi pernyataan dan kesan (Sayuti, 2000: 7). Dalam sajak bertebaran kata yang telah dipadatkan sedemikian rupa. Kata yang bisa 
dimaknai apa adanya sebagai kata yang memiliki makna denotasi, maupun kata yang memiliki makna konotasi.

Hubungan denotasi dan konotasi terletak pada notasi atau rujukannya (Parera, 2004: 97). Apabila sebuah kata dikatakan bermakna denotasi, ia dimaknai apa adanya, sesuai dengan kamus dan terbatas. Sementara untuk kata yang memiliki makna konotasi, ia telah memperoleh tambahan perasaan yang berupa nilai rasa, emosi tertentu, prasangka tertentu yang sering tak terduga.

Penggunaan bahasa dalam sajak adalah penggunaan bahasa yang penuh rangsangan konotasi. Konotasi yang merangsang dan menggugah pancaindra, perasaan, sikap, penilaian, keyakinan, dan keperluan tertentu. Puisi menghidupkan dan menyadarkan kita pada sifat metaforis bahasa (Wellek dan Austin Warren, 1995: 22). Dalam puisi kita disajikan pengalaman sehari-hari seperti tambang kenangan.

Pengalaman sehari-hari yang menjadi tanaman pangan bagi ruang hati. Seperti baris puisi Goenawan Muhamad Mengekalkan yang esok mungkin tak ada, menjadi sebuah rekaman serupa gema yang akan bergaung kembali tatkala kita membaca ulang sajak-sajak itu (Zaidan, 2004:26). Sehingga akan terus bisa dinikmati dan digali makna yang terkandung di balik puisi.

Seperti itulah hendaknya perlakuan pada puisi-puisi yang ada. Perlu apresiasi yang berangkat dari hasrat untuk menggali sebanyak-banyaknya tambang "ruang hati". Dengan berpegang pada anggapan bahwa sebuah puisi bukan sesuatu yang asal jadi, dipilihlah puisi karya Soni Farid Maulana.

Soni Farid Maulana merupakan salah satu penulis puisi Indonesia yang sudah tak asing lagi bagi pecinta puisi di Indonesia. Salah satu kumpulan puisinya bisa dinikmati pada bukunya yang berjudul "Kita Lahir sebagai Dongengan". Baginya menulis puisi adalah semacam upaya mengaktualisasikan diri di tengahtengah benturan nilai-nilai yang dari waktu ke waktu demikian cepat berubah (Maulana, 2000: 117). Pada buku tersebut ditampilkan puisi-puisi pilihan karya Soni Farid Maulana sebagai hasil daya kreatifnya, permainan kata-kata, bahasa, dan lambang yang dituturkannya lewat puisi.

Berpegang pada pandangan bahwa latar sangat penting dalam sajak (Damono, 2014: 39), dipilihlah beberapa sajak yang dipandang memiliki kemiripan latar dalam sajiannya. Dengan dibatasi pada rumusan masalah "Apa makna kata hujan dan sejauh mana mendukung nada dan suasana dalam puisi karya Soni Farid Maulana?".

Tujuan dilakukan analisis ini, berangkat dari rumusan masalah, untuk mengetahui makna denotasi dan konotasi dari kata hujan dalam puisi karya Soni Farid Maulana dan seberapa besar pengaruh latar hujan mendukung suasana puisi yang ingin diungkapkan oleh penyair. Hal itu akan coba diungkapkan dengan pertama-tama mengonsentrasikan pada nada dan suasana yang tertangkap dari latar yang ditampilkan dalam puisinya. 
Adapun pendekatan yang digunakan adalah pendekatan struktural semiotik. Hal itu berdasarkan pandangan bahwa unsur dasar dalam susunan teks puisi bukanlah kalimat, melainkan larik-larik sajak (Luxemburg, dkk. 1992: 185). Dalam hal ini, yang dipentingkan bagaimana kata-kata dalam sebuah puisi memperoleh suatu makna tambahan karena bentuk larik sajak.

Struktur sajak dapat menimbulkan kaitan-kaitan antara berbagai kata dalam sebuah sajak, lepas dari hubungan logik-sintaktik (Luxemburg, 1992: 186). Kaitan itu misalnya terjadi karena letak kata yang serupa dalam larik sajak. Khusus letak pada awal dan akhir larik itu penting, karena posisi itu dengan sendirinya lebih ditekankan. Kaitan itu bisa juga terjadi karena kemiripan bunyi. Sebuah hubungan formal berdasarkan posisi yang ekuivalen dan analogi bunyi sekaligus mengandung suatu jaringan relasi semantik. Susunan sebuah sajak mempengaruhi makna totalnya.

Salah satu akibat semantisasi ini ialah sebuah kata dengan mendadak memperoleh suatu arti yang menyimpang dari arti biasa. Kadangkadang karena pengaruh konteks artiarti samping dihidupkan, bahkan kadang-kadang sebuah kata memperoleh arti yang serba baru.

\section{KERANGKA TEORI}

Hakikat pemahaman makna atau apresiasi puisi mengacu pada pengertian pengenalan, pertimbangan, penilaian, dan pernyataan yang memberikan penilaian. Ada upaya untuk menggauli cipta sastra dengan sungguh-sungguh sehingga tumbuh pengertian, penghargaan, kepekaan pikiran kritis, dan kepekaan perasaan yang baik karya puisi.

Mengapresiasi puisi merupakan wujud hubungan langsung yang terjalin antara karya sastra dan pembaca. Dalam apresiasi sastra hubungan langsung antara pembaca dan pengarang sama sekali tidak penting (Damono, 2014: 2). Bagi pengapresiasi, membaca karya jauh lebih penting daripada mengenal secara langsung pengarangnya.

Mengingat bahasa puisi yang bersifat sugestif, asosiatif, dan imajinatif inilah, para ahli sastra mengatakan, bahwa hakikat puisi adalah citraan (imaji); bagaimana puisi itu mengungkapkan banyak hal melalui bahasa yang padat, lugas, dan bernas. Akibatnya, terbuka peluang yang begitu luas kepada pembaca untuk menafsirkan sendiri puisi yang bersangkutan. dan semakin banyak tafsiran, semakin tinggi nilai karya itu.

Sungguhpun ada kebebasan dan keleluasaan dalam mengapresiasikan sebuah puisi, apresiator perlu juga membekali diri dengan pemahaman tentang bagaimana apresiasi puisi itu dilakukan. Sebuah apresiasi yang logis, argumentatif, dan meyakinkan sehingga kekayaan makna puisi dapat diungkapkan lebih mendalam. Oleh karena itu, ada beberapa langkah yang perlu dilakukan dalam melakukan tindak apresiasi puisi. 
Salah satu langkah yang diambil dalam mengapresiasi puisi adalah melalui pengamatan titik pandang (point of view) yang digunakan. dengan mencermati beberapa pertanyaan berikut ini:

(1) Siapa yang berbicara; aku liris, engkau liris, dia liris, atau subjek liris;

(2) Kepada siapa berbicara; kepada sesama manusia, alam, Tuhan atau dirinya sendiri;

(3) Apa yang dibicarakan; dirinya sendiri, orang lain, masyarakat, alam atau apapun;

(4) Bagaimana ia berbicara; bersemangat, sedih, datar, marah atau gembira (Luxemburg, dkk. 1992).

Walaupun pandangan setiap orang tentang arti puisi itu berbeda-beda. Akan tetapi puisi yang disajikan harus mempunyai makna dan tujuan tertentu tergantung penyair membuatnya. Sehingga puisi tersebut bisa dinikmati oleh pembaca. Oleh karena itu, perlu diperhatikan bahwa puisi mempunyai 2 unsur yaitu unsur batin dan unsur fisik.

\section{Unsur Batin}

\section{Tema}

Tema merupakan gagasan pokok yang dikemukakan oleh penyair melalui puisinya. Ada beberapa sifat tema dalam puisi yang berfungsi untuk mempermudah dan menghindari kesalahan penafsiran tema, Diantaranya:

a. bersifat khusus (diacu oleh penyair)

b. objektif (semua pembaca harus sama) c. lugas (tidak bermakna kias yang di ambil dari konotasinya)

\section{Perasaan}

Perasaan yaitu suatu keadaan kerohanian atau peristiwa kejiwaan yang sedang dialami dan dïrasakan. Perasaan sangat berpengaruh terhadap rangkaian kata. Supaya pembaca mampu mengespresikan puisi tersebut sesuai dengan makna yang terkandung dalam puisi tersebut.

\section{Nada dan Suasana}

Nada puisi yaitu sikap batin penyair yang hendak diekspresikan kepada pembaca. Nada menimbulkan suasana tertentu terhadap pembacanya. Nada pun sangat mendukung ekspresi. Sedangkan suasana itu sendiri adalah keadaan jiwa pembaca setelah membaca puisi. Jadi nada dan suasana itu saling terkait untuk menjiwai sebuah puisi

\section{Amanat}

Merupakan maksud,tujuan atau himbauan yang hendak di sampaikan penyair melalui puisinya. Penghayatan terhadap amanat sebuah puisi bersifat subjektif,tergantung pada interprendensi pembacanya. Biasanya seorang penyair menyampaikan amanah itu menggunakan bahasa yang mengandung makna-makna idiomatik seperti pepatah,peribahasa,dan majas.

\section{Unsur Fisik}

\section{Diksi}

Karena puisi adalah bentuk karya sastra yang sedikit kata-kata tapi dapat mengungkapkan banyak hal. Penyair 
harus memilih kata-kata yang cermat. Selain itu penyair juga harus mempertimbangkan urutan kata dan daya magis kata yang diberi makna oleh penyair

\section{Pengimajian}

Imajinasi sangatlah di Perlukan untuk membuat puisi dan mempermudah penyair untuk menyampaikan pengalaman batin yang di alami. Penyair harus memilih katakata tepat agar dapat memperkuat serta memperjelas daya bayang pikiran dan energi tersebut dapat mendorong untuk menjelmakan gambar nyata.

\section{Konkrit}

Untuk dapat membagun daya imajinasi pembaca. Kata-kata dalam puisi harus di perkonkrit. Artinya katakata itu dapat mengarah pada arti secara keseluruhan dengan menggunakan bahasa kias dan lambang. Sedangkan arti konkrit itu sendiri adalah kata-kata yg di lihat secara denotatif sama,tetapi secara konotatif tidak sama karena di sesuaikan dengan kondisi dan situasi

\section{Majas}

Majas adalah cara yang di gunakan oleh penyair untuk membangkitkan dan menciptakan imagi dengan menggunakan gaya bahasa,gaya perbandingan,gaya kiasan,gaya pelambang sehingga semakin jelas makna atau lukisan yang dihendaki penyair lewat puisinya. Majas menyebabkan puisi menjadi prismatis,artinya memancarkan banyak makna atau kaya makna.

\section{Rima}

Puisi yang tersusun oleh katakata sehingga menjadi kalimat bermakna tidak terlepas oleh permainan bunyi yang di ciptakan penyairnya untuk memberikan efek tertentu. Pola-pola pengulangan bunyi dalam puisi disebut rima. Rima dibedakan menjadi dua yaitu asonansi (pengulangan bunyi vokal) dan aliterasi (pengulangan bunyi konsonan). Bunyi asonansi $(\mathrm{a}, \mathrm{i}, \mathrm{u}, \mathrm{e}, \mathrm{o})$ akan menghasilkan efek berupa kemerduan, kerinduan, kemesraan, keindahan, dan kegembiraan sedangkan aliterasi, (k,p,n,b,r) akan memberikan efek berupa kekacauan, kehancuran, kebisingan

\section{Tipografi}

Tipografi adalah tampilan fisik yang membedakan antara puisi dengan karya sastra lainnya.

Matheuw Arnold, Stageberg, dan Anderson memandang puisi sebagai refleksi dari pemikiran dan bukan tidak mungkin mengantarkan kita pada dunia pemikiran dan perasaan (Prijanto dan Tasai (Eds), 2003: 53). Sehingga ada pendapat bahwa aspek pemikiran merupakan bagian dari keberhasilan estetika sebuah karya sastra (Prijanto dan Tasai (Eds), 2003: 53).

Puisi datang pertama kali lewat nadanya (Prijanto dan Tasai (Eds), 2003: 30). Nada puisi yaitu sikap batin penyair yang hendak diekspresikan kepada pembaca. Nada menimbulkan suasana tertentu terhadap pembacanya. 
Nadapun sangat mendukung ekspresi. Ada puisi yang bernada sinis, protes, menggurui, memberontak, main-main, serius, patriotik, belas kasih (memelas), takut, mencekam, santai, masa bodoh, pesimis, humor, dan sebagainya (Waluyo, 2002:37).

Puisi memiliki unsur yang lengkap dan padat daripada prosa, seperti bunyi, irama, pembagian irama, pemilihan kata-kata, kombinasi kata, bahasa kiasan, dan gaya bahasa (Pradopo, 2003: 62). Dalam memahami puisi tidak mungkin tanpa diperhatikan aspek komunikatifnya, dengan kata lain, tanpa pendekatan sastra sebagai tanda, atau sebagai gejala semiotik (Teeuw, 1984: 43).

\section{METODE PENELITIAN}

Metode yang digunakan dalam analisis ini adalah deskriptif kualitatif dengan pendekatan semiotik. Pengumpulan data berupa teknik catat. Dengan langkah-langkah teknik pengolahan data berupa menentukan puisi yang akan dikaji. Membaca berulang-ulang puisi yang terpilih. Mengidentifikasi, menandai, dan memberi kode kata, frase, atau lariklarik pada puisi terpilih.

Analisis difokuskan pada kehadiran kata 'hujan' dilihat dari makna denotasi maupun makna konotasi. Memperhatikan kata 'hujan' sebagai latar yang mendukun suasana yang ingin dikomunikasikan penyair pada pembacanya.

Data utama sebagai objek kajian terpilih adalah puisi Soni Farid Maulana. Data bersumber dari buku kumpulan puisi Karya Soni Farid Maulana dalam buku kumpulan puisinya yang berjudul Kita Lahir Sebagai Dongengan, Sajak Pilihan Soni Farid Maulana.

\section{ANALISIS DAN PEMBAHASAN}

Puisi yang dipilih untuk dianalisis ada lima judul. Puisi dipilih dari buku kumpulan puisi karya Soni Farid Maulana yang berjudul "Kita Lahir sebagai Dongengan". Sengaja dipilih lima judul puisi yang semuanya memuat kata "Hujan". Hal itu dengan asumsi dasar bahwa kata hujan sebagai salah satu peristiwa alam penanda latar alam.

Adanya kesamaan kata "Hujan" dalam puisi terpilih menjadi penanda adanya citraan suasana hujan yang ditemukan dalam kelima puisi yang dianalisis. Dalam puisi terdapat berbagai pola makna. Bagi puisi yang merupakan gejala paling khas yakni makna tambahan yang terjadi berdasarkan bentuk sajak. Diyakini adanya jaringan hubungan formal berdasarkan posisi yang ekuivalen dan analogi relasi semantik.
Hujan Malam
Bahkan bayang-bayangku
Meninggalkan diriku di kamar ini
Ketika lampu mati tiba-tiba, ketika petir
Menyambar gardu listrik saat hujan jatuh
Dengan amat derasnya. Tak ada siapa-siapa
Dalam kamar kontrakan 2x3 meter, Selain setumpuk baju, baju lusuh


Belum dicuci juga detik jam dan dengung

Nyamuk. Seperti dirimu, bayangbayangku

Malam itu meninggalkan diriku.

Tanpa sepatah kata pun yang kau ucap,

Ketika kau torehkan warna sepi

Pada daun pintu yang kau tutup perlahan.

Malam datang padaku saat itu bagai usungan

Mayat tanpa kepala. Dingin tak bertepi

1987

Puisi 'aku' lirik tersebut ditujukan kepada seseorang yang dianggapnya sebagai 'bayangnya'. Kesepian yang menyergap tiba-tiba pada si 'aku' lirik ditunjukkan dengan gambaran keberadaan dalam kamar kontrakan $2 x 3$ meter bersama detik jam, tumpukan buku dan baju lusuh, serta dengung nyamuk. Ditingkah suara hujan jatuh.

Citraan penglihatan tentang hujan yang deras, hujan disertai petir sehingga menyebabkan kegelapan yang tiba-tiba. Sebuah gambaran kegelapan sebagai metafora rasa kehilangan yang menyergap tiba-tiba. Si 'aku' lirik ingin menyampaikan sepi tak bertepi yang menyergapnya. Sebuah gambaran ketidaktentuan. Ketidakjelasan yang disertai ketakutan yang mencekam yang ditegaskan pada dua baris terakhir terakhir, Malam datang padaku saat itu bagai usungan//Mayat tanpa kepala.

Pada puisi di atas kata 'hujan' diulang dua kali, yakni pada judul dan pada baris keempat. Hujan sebagai penguat suasana berupa peristiwa alam yang mendukung suasana sepi yang dirasakan 'aku' lirik. Sepi yang menunjukkan ketidakjelasan, gelap gulita, dan ketakutan yang mencekam.

\section{Sehabis Hujan}

Tak ada yang kekal di bumi

Semua kembali padamu. Tanah merah

Bayang-bayang pohonan

Serpihan bunga juga sehimpun doa

Angin bertiup perlahan

Sebuah ruang terasa sunyi di dada selebihnya sisa butiran airmata

Berkilat di punggung waktu 1990

Puisi 'aku' lirik tersebut sebagai buah kesadaran tentang arti kehilangan. Bagaimana ia mengembalikan semua yang ada tak ada yang kekal. Semua yang ada di bumi akan kembali padamu. Ungkapan hati kepada yang merupakan pemilik segala. Bersatu dengan Tanah merah sebagai metafora dari tanah pekuburan. Dilengkapi dengan taburan bunga dan diiringi sehimpun doa dari para pengantar jenazah.

Kata hujan hanya muncul satu kali, yakni pada judul puisi tersebut. Kata hujan sebagai pendukung berupa latar alam yang menggambarkan sebuah suasana sendu. Basah, dalam tetesan air mata. Sehabis Hujan yang bisa dimaknai bahwa saat hujan berlalu, aktivitas berlanjut. Hidup harus terus berjalan. Semua yang terjadi di pandang sebagai bagian dari punggung waktu.

Laksana hujan yang rinainya membawa kesyahduan, namun akan 
lenyap setelah hujan berlalu. Begitulah hidup harus dihadapi, karena hidup adalah menunggu giliran menghadap Ilahi, kembali menyatu dengan tanah merah. Latar hujan mewakili suasana kesyahduan perasaan kehilangan. Kehilangan yang harus dihadapi sebagaimana saat sehabis hujan.

\section{Lagu dalam Hujan}

Di dalam ruang penjara yang pengap dan lembab,

Di kedalaman dada

Sebaris hujan mendekap sehimpun kata

Yang mati bunuh diri. Di situ ada pula sekuntum mawar

Daging dan kelopaknya tersayat pecahan beling

Langit kelam dan dalam. Ajal berlayar di hati

Derit pintu yang membuka dan menutup sungguh

Tajam menikam pendengaran

Cuaca yang basah menandai lolong anjing hitam

Yang menyeruak dari dasar kuburan

Nyawa yang terbaring di atas ranjang

Kian menguning bagai lembaran rekening listrik

Di atas meja, sarat debu.

Kini aku bertanya padamu; masihkah

Ada ruang yang kedap suara bahkan steril

Bagi setiap persoalan yang kita percakapkan

Di situ? Udara yang kuhirup bertuba

Sedang alam yang hijau dikekalkan
Wahdi*); jauh dari incaran ulat kota besar

Yang lapar dan rakus; begitu lahap Menyikat segala tumbuhan juga perbukitan,

Lalu pekuburan menjelma perumahan

\section{4}

*) alm. Wahdi salah seorang pelukis yang setia dengan gaya ucap Mooi Indie

Puisi 'aku' lirik di atas mengutarakan perasaan yang dikungkung oleh penjara yang tak nampak. Pembatasan pada pengungkapan isi Di kedalaman dada. Rintangan yang begitu banyak yang dimetaforakan sebagai rinai hujan sehingga sanggup menahan sehimpun kata yang bahkan bisa menyebabkan kedatangan ajal bagi hati.

Upaya mengkonkritkan keadaan pengekangan suara-suara hati pada puisi diwakili dengan citra pendengaran dan penglihatan lolong anjing hitam//Yang menyeruak dari dasar kuburan. Disandingkan dengan pengungkapan lukisan pemandangan alam yang hijau dikekalkan oleh pelukis Wahdi. Walau alam hijau itu telah menjelma sebagai perumahan.

Kata 'hujan' hadir dua kali. Pertama pada baris judul dan yang kedua pada bait pertama baris ketiga. Kata hujan hadir sebagai gambaran suasana yang menjadi simbol adanya rintangan yang mendekap sehimpun kata. Bukan hanya 'kata' yang tertahan bahkan bibit kata itu pun tertahan dengan metafora sekuntum mawar yang tersayat pecahan beling. Hujan sebagai latar alam yang mendukung suasana tertekan. 


\section{Melangkah dalam Hujan}

Melangkah dalam hujan

Membaca huruf-huruf yang tertera

Pada lembar demi lembar guguran daun

Jiwaku takut dan gemetar

Terasing dan sunyi di tengah hujan

Yang turun dari langit yang lain

Dari kelam kabut perasaan. Ruh yang berlayar

Dalam daging tersesat di cairan anggur

Mengambang di genangan bir.

Sekejap, hanya

Sekejap kilat menghanguskan pepohonan

Menghanguskan rerumputan jiwaku

Yang dalam. Berjalan dalam derai hujan

Jarum-jarum air yang dingin dan runcing

Tembus ke tulang parat ke liang nyawa

Aliran darah terasa beku

Daging-daging membiru mungkin kelabu

Kurasakan nyawaku terengahengah

Menyisir daging yang fana yang kelak

Membusuk dalam tanah.

Daging, ya, selalu daging dengan

Bentuk sepasang buah pir atau

Celah lembut berbukit yang kerap

Kau pamerkan. Sekali lagi

Selalu daging bikin nyawaku

Ngambang dan berpusar di udara

Diguyur hujan yang turun

dari langit yang lain

1996

Puisi 'aku' lirik tersebut sebagai ungkapan ketakutan dalam kenikmatan yang dirindukan. Bagaimana si 'aku' mengutarakan di bait pertama rasa takut sehingga gemetar. Sebuah ironi yang ditegaskan dengan gambaran nyawaku//Ngambang dan berpusar di udara. Sebuah konkritisasi tentang keadaan jiwa yang sedang melayang.

Ada pengulangan kalimat hujan//Yang turun dari langit yang lain pada baris 5 ke 6 dan baris 26 ke 27 . Pengulangan tersebut ditanggapi sebagai sebuah penegasan keadaan yang dialami oleh penyair. Keadaan 'hujan' yang bukan hujan biasa karena dari langit yang lain.

Kata 'hujan' diulang lima kali pada puisi tersebut. Pada judul dan diulang lagi pada baris pertama, bait pertama. Pada baris kelima bait pertama kata 'hujan' sebagai latar suasana hati yang Terasing dan sunyi. Tentang kelam kabut perasaan. Latar 'hujan'mendukung suasana hati orang yang mengalami kontemplasi yang diwakili dengan kalimat Ruh yang berlayar//Dalam daging tersesat di cairan anggur//Mengambang di genangan bir.

Hujan tak lagi menjadi rinai tetapi hujan yang disertai kilat yang menghanguskan

pepohonan//Menghanguskan rerumputan jiwaku//Yang dalam. Menuntun pada pemaknaan tentang hujan yang turun//Dari langit yang lain. Gambaran gemuruh 'hujan' yang ada dan hanya dirasakan oleh si aku lirik.

\section{Hujan Turun di Aceh}

Hujan turun lagi malam ini

Bagai uap es dalam kulkas udara yang dingin

Menyelusup ke dalam sumsum kata-kata 


Hingga larik-larik sajakku
menggigil dibuatnya
Seperti seorang ibu tua
Ketika matanya menatap tidak
percaya akan lobang kuburan
Yang baru digali -- berisi dua belas
tengkorak
Adakah satu di antaranya
tengkorak anakku

Hujan pun amis darah

Tidak hanya turun di Aceh. Deras juga

Di Haur Koneng, Ambon, Lampung, Sampang, Irian

Serta di kota-kota tak terduga dalam peta.

Ketika kubuka jendela apa yang kupandang

Selalu kelam bersambung kelam

Lalu angin mendesir

Dari tangkai ke tangkai pohonan menandai salak anjing

Negeri kegelapan

Kini tidak hanya peluh juga keluh

Dibalut impian menakutkan yang dating

Berulang. Lebih gosong dari sesosok tubuh

Yang hangus dibakar dalam sebuah

Kerusuhan Mei lalu di Jakarta

Dan hujan pun amis darah

Turun juga di situ

1998

'Aku' lirik mengabadikan rentetan peristiwa sedih yang terjadi di tanah air. Tentang bencana alam di Aceh. Tentang tragedi yang terjadi di tanah air. Tentang huru-hara di ibukota. Penyair mengabadikan dengan metafora yang cukup lugas sebagai peristiwa Hujan amis darah. Peristiwa demi peristiwa diwakili dengan penyebutan wilayah terjadinya peristiwa yang menguras air mata. Hujan pun amis darah//Tidak hanya turun di Aceh.//Deras juga di Haur Koneng, Ambon, Lampung, Sampang, Irian. Tidak hanya di daerah-daerah lain di seantero Indonesia. Jakarta sebagai ibukota pun tak luput dari hujan pun amis darah//Turun juga di situ.

Peristiwa-peristiwa yang membangkitkan rasa miris, kesedihan yang luar biasa. Kerusuhan di kota yang selama ini tak menjadi titik sentral dalam peta kemungkinan terjadinya huru hara //Serta di kota-kota tak terduga dalam peta.

Kesedihan yang menjadi muara dari puisi yang dibuatnya yang ditegaskan dengan Hingga larik-larik sajakku menggigil dibuatnya.

Kesedihan dilengkapi dengan latar 'hujan'. Kata 'hujan' hadir diulang 4 kali pada puisi tersebut. 'Hujan' menjadi latar kesedihan yang mendalam yang menjadi kisah yang ingin disampaikan penyair kepada pembaca. Bagaimana kisah sedih itu menjadi embun airmata laksana uap es dalam kulkas udara yang dingin//Menyelusup ke dalam sumsum kata-kata puisi yang tercipta.

\section{PENUTUP}

Latar sangat penting dalam sajak karena memberikan suasana yang sangat diperlukan dalam usaha kita menafsirkan puisi (Damono, 2014: 39). Masing-masing latar membantu pembaca membayangkan situasi dan suasana yang diperlukan untuk melatari peristiwa. Kadang-kadang sebuah sajak malah bisa hanya merupakan latar saja, tanpa 'peristiwa' yang diungkapkan; jadi, suasana itu sendirilah peristiwanya. 
Pada lima puisi yang telah dianalisis, tampak bahwa latar berupa peristiwa alam yakni 'hujan'menjadi pendukung nada dan suasana yang ingin disajikan 'aku' lirik. Suasana hujan yang identik dengan basah, dingin, syahdu, mendukung suasana dalam lima puisi tersebut.

Pada puisi "Hujan Malam", hujan dimaknai sebagai peristiwa jatuhnya air dari langit. Latar hujan mendukung suasana sepi yang menunjukkan ketidakjelasan, gelap gulita, dan ketakutan yang mencekam. Sementara pada puisi "Sehabis Hujan", hujan dimaknai sebagai peristiwa alam yang saat berhenti, sisa hujan akan diserap tanah. Tanpa sisa dan bekas. Latar hujan mendukung suasana kesyahduan perasaan kehilangan.

Pada puisi "Lagu dalam Hujan" Kata hujan dipersonifikasikan sebagai sesuatu yang dapat merintangi. Hujan sebagai latar alam yang mendukung suasana tertekan. Pada puisi tersebut tampak bahwa dalam hujan, dalam kesyahduan, ada kekuatan yang dapat menahan orang untuk beraktivitas.

Adapun dengan kata hujan dalam puisi "Melangkah dalam Hujan", hujan dimaknai pengalaman birahi yang dialami oleh si 'aku' lirik. Hujan sebagai latar yang mendukung suasana syahdu ketika rinai hujan turun dalam volume biasa, menjadi mengerikan ketika rinainya disertai petir. Hujan dimetaforakan sebagai gambaran gemuruh 'hujan' yang ada dan hanya dirasakan oleh si aku lirik.

Pada puisi "Hujan Turun di Aceh" hujan dimaknai sebagai salah satu peristiwa alam. 'Hujan' menjadi latar kesedihan yang mendalam. Hujan pun dimetaforakan sebagai bencana yang membawa korban. Bencana baik yang berupa peristiwa alam maupun peristiwa kerusuhan yang terjadi di kota-kota yang disebutkan dalam puisinya.

\section{DAFTAR PUSTAKA}

Damono, Sapardi Djoko. 2015. Bilang Begini Maksudnya Begitu. Jakarta: Gramedia.

Luxemburg, Jan Van, Mieke Ball, Willem G. Westeijn. Tanpa tahun. Pengantar Ilmu Sastra. Terjemahan oleh Dick Hartoko. 1992. Jakarta: Gramedia.

Maulana, Soni Farid. 2000. Kita Lahir Sebagai Dongengan, Sajak Pilihan Soni Farid Maulana. Magelang: Indonesia Tera.

Parera, JD. 2004. Teori Semantik Edisi Kedua. Jakarta: Erlangga.

Pradopo, Rahmat Djoko. 2003. Prinsip-Prinsip Kritik Sastra. Yogyakarta: Gadjah Mada University Press. 
Prijanto, Saksono dan S. Amran Tasai. 2003. Antologi Esai Sastra Tentang Karya Subagio Sastrawardojo. Jakarta: Pusat Bahasa Departemen Pendidikan Nasional.

Sayuti, Suminto A. 2000. Semerbak sajak. Yogyakarta: Gama Media.

Teeuw, A. 1984. Sastra dan Ilmu Sastra, Pengantar Teori Sastra. Jakarta: Pustaka Jaya.

Wellek, Rene and Austin Warren. Tanpa tahun. Teori Kesusastraan. Terjemahan oleh Melani Budianta. 1995. Jakartta: Gramedia

Waluyo, Herman J. 2002. Apresiasi Puisi untuk Pelajar dan Mahasiswa. Jakarta: PT. Gramedia Pustaka Utama.

Zaidan, Abdul Rozak. 2004. Ironi dalam Sajak-Sajak Goenawan Mohamad dalam Jurnal Pangsura Juli-Desember 2004. Brunei Darussalam: Processta 